Dept. of Food Hygiene,

Animal Health Research Institute, Dokki, Giza.

\title{
A PILOT STUDY ON COPPER LEVEL AMONG DOMESTIC ANIMALS IN ISMAILIA GOVERNORATE
}

(With One Table)

By

\author{
K.M. EL-KHAWAS; SUZAN M. ABO-ZEID \\ and M.K. ABO-ELMAGD
}

(Received at 17/6/2007)

\section{دراسة عن مستوى عنصر النحاس فى حيوانات الحقل بمحافظة الاسماعيلية خالد الخواص ، سوزان محمد أبو زبإ ، محد كمال أبو المجل}

نظر الأهمية تأثير بقايا المعادن فى الأنسجة الحيوانية على صحة الحيوان وسلامة الأغذية

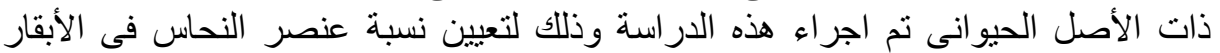
والجاموس والجمال والخر اف والماعز فى محافظة الاسماعيلية ـ مصر باستخدام جهاز

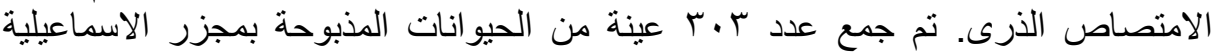

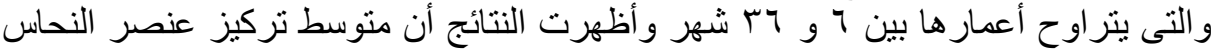

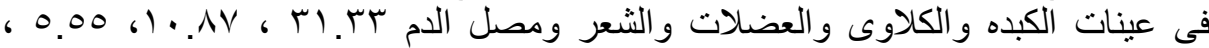

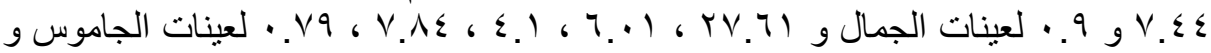

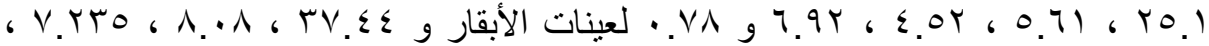

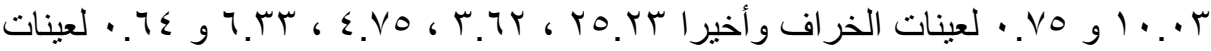

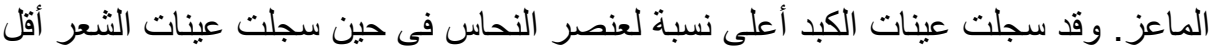

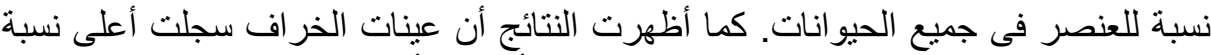
للعنصر تليها عينات الجمال ثم الجاموس ثم الماعز وأخير التئ الأبقار .

\section{SUMMARY}

Monitoring levels of mineral concentrations in animal tissues is important for assessing the effect of contamination on animal health and safety of animal origin products in human nutrition. This study evaluated the levels of copper in cattle, buffaloes, camels, sheep and goats reared in Ismailia Governorate, Egypt. Samples of 303 animals aged 6-36 months were collected from the Governorate slaughterhouse at slaughtering and analyzed after acid digestion using atomic absorption spectrophotometer (AAS). The mean concentrations obtained per wet weight (ppm) for liver, kidney, muscle, hair, serum were 31.33, 10.87, $5.55,7.44$ and 0.90 in camels; 27.61, 6.01, 4.10, 7.84, and 0.79 in 
buffaloes ; 25.10, 5.61, 4.52, 6.92 and 0.78 in cows; 37.44, 8.08, 7.235, 10.03 and 0.75 in sheep and $25.23,3.62,4.75,6.33$ and 0.64 in goats. The highest concentration of copper was in liver while the lowest was in hair for all animals. The results indicated that sheep had the higher liver copper concentrations, followed by camels, buffaloes, goats and then cows.

Key words: Copper, trace elements, domestic animals.

\section{INTRODUCTION}

Copper is an essential trace element for human and animals. Its deficiency is known to cause anemia, diarrhea, bone disorders, neonatal ataxia, changes in hair and wool pigmentation, infertility, cardiovascular disorders, impaired glucose and lipid metabolism and a depressed immune system (Davis and Mertz, 1987). Copper is a key component of many enzyme systems which when impaired can directly or indirectly cause many of the symptoms of copper deficiency.

Because many of the copper deficiency symptoms are general in nature, a clear diagnostic tool that accurately reflects the copper status of the animal is needed. Although serum and plasma copper concentrations are often measured, blood levels may not show the deficiency until severe symptoms develop (Hemken et al., 1993). Liver copper concentration is probably the most sensitive indicator of changes in copper status and its determination is recommended when liver biopsies can be obtained. Ceruloplasmin concentrations and superoxide dismutase activity in the blood or red blood cells can be useful indicators of copper status.

Dietary copper requirements vary greatly among species. The recommended levels for one species may cause toxicity in another. For example, $10 \mathrm{ppm}$ is the NRC recommended level for dairy cattle but under certain conditions $10 \mathrm{ppm}$ can cause toxicity in sheep (Church and Pond 1988). By comparison, growing pigs are often fed 100 to $250 \mathrm{ppm}$ of copper in the diet to improve growth. According to the National Research Council, poultry require approximately 8 ppm copper.

The daily copper requirement for different animals recorded in ppm as: swine 5-6; poultry 6-8; horses 9 ; dairy cattle $12-16$; beef cattle 10 (4-15); sheep 7-11; and goats 10, other animals 0.4-7.3. While toxic level in total diet (ppm) as: swine >250; poultry 250-500; dairy cattle 40; beef cattle 100; sheep 25; goats 8-25. (Larry, 1994) 
In the liver the adequate amount of copper is 25 to $100 \mathrm{ppm}$ wet weight and in the bovine serum falls between 0.60 and $1.50 \mathrm{ppm}$ wet weight (Puls, 1994).

In the present investigation we tried to give an indicator about copper level among cattle in Ismailia Governorate through EFARP (Egyptian Finnish Agriculture Research Project).

\section{MATERIALS and METHODS}

Three hundred and three Samples including blood for serum separation, liver, kidney, muscles, hair and wool were collected from cattle, buffaloes, camels, sheep and goats at Ismailia Governorate. These samples were collected when the animals were slaughtered; samples then transported immediately on ice to the laboratory and kept in deep freezer at $-18^{\circ} \mathrm{C}$ until digestion.

Blood serum samples were diluted with n-butanes: bidistilled water $(6: 94 \mathrm{v} / \mathrm{v})$ and analyzed for copper by atomic absorption spectrophotometer model Aurora AI 1200 according to Meret and Henkin (1971).

Tissue samples, hair and wool were analyzed for copper after wet ashing by a mixture of nitric and perchloric acids on hot plate as descried by Valentine et al. (1987). One gram portion of sample was digested in $10 \mathrm{ml}$ of nitric acid / perchloric acid 1:1. Digestion continued on hot plate until organic matter was destroyed and the solution evaporated to dryness. To each of digested sample, $15 \mathrm{ml}$ of $6 \mathrm{~N} \mathrm{HCl}$ was added and used for copper measurement

\section{RESULTS}

Table 1: Copper content (mean \pm SE) in samples collected from apparently healthy animals at slaughtering.

\begin{tabular}{|c|c|c|c|c|c|c|}
\hline \multirow{2}{*}{ Animal } & \multirow{2}{*}{$\begin{array}{c}\text { Number } \\
\text { of } \\
\text { Animals }\end{array}$} & \multicolumn{5}{|c|}{$\mathrm{Cu}$ content (ppm weight) } \\
\hline & & Liver & Kidney & Muscle & Hair & Serum \\
\hline Camels & 15 & $31.33 \pm 3.41$ & $10.87 \pm 3.48$ & $5.55 \pm 1.50$ & $7.44 \pm 2.01$ & $0.90 \pm 0.15$ \\
\hline Buffaloes & 125 & $27.61 \pm 2.88$ & $6.01 \pm 0.51$ & $4.10 \pm 0.30$ & $7.84 \pm 0.48$ & $0.79 \pm 0.05$ \\
\hline Cows & 98 & $25.10 \pm 3.00$ & $5.61 \pm 0.43$ & $4.52 \pm 0.37$ & $6.92 \pm 0.90$ & $0.78 \pm 0.08$ \\
\hline Sheep & 49 & $37.44 \pm 6.09$ & $8.08 \pm 1.64$ & $7.23 \pm 1.35$ & $10.03 \pm 1.90$ & $0.75 \pm 0.14$ \\
\hline Goats & 16 & $25.23 \pm 0.67$ & $3.62 \pm 0.59$ & $4.75 \pm 1.44$ & $6.33 \pm 1.61$ & $0.64 \pm 0.10$ \\
\hline
\end{tabular}




\section{DISCUSSION}

Copper is a component of several enzyme systems and the measurement of these could provide a more accurate measure of rate limiting factors associated with copper deficiency (Gay et al., 1988)

Distribution of total body copper will vary with species, age and copper status, but it is generally higher in the tissues of liver, brain, kidneys, heart and hair. In ruminants, normal liver storage of copper can be very high as compared to other species, since liver (dry matter basis) normally contains approximately 100 and $400 \mathrm{ppm}$ for mature cattle and sheep, respectively (Bull,1980)

Liver is the main storage organ of copper and is currently considered the tissue of choice for most accurate measurements of copper status (Claypool et al., 1975). In this study liver copper concentrations (mean \pm SE) in camels, buffaloes, cows, sheep and goats (Table, 1) are 31.33 $\pm 3.41,27.61 \pm 2.88,25.10 \pm 3.00,37.44 \pm 6.09$ and $25.23 \pm 0.67$ respectively.

The results indicate that local bread sheep had the higher liver copper concentrations, followed by camels, buffaloes, goats and then cows. Underwood (1977) found that normal copper concentrations of liver tissues will vary with species, age and the disease condition of the animal. Lazzaro (2007) recorded that copper accumulate in the liver of sheep more readily than other farm animals while, Phillippo and Graca (1983) described that cattle limiting hepatic storage sooner than sheep by means of biliary secretion. Moreover, Zervas et al. (1990) observed that goats retain less copper in their livers than sheep when exposed to excess, presumably because they share with cattle a propensity for billiary copper secretion.

While, the mean values of liver copper concentrations in local animals are above concentrations considered to be indicative for copper deficiency, copper concentration below $10 \mathrm{ppm}$ wet tissue are found in $11.11 \%$ of camel, $14.44 \%$ of buffaloes, $32.86 \%$ of cows, $10.34 \%$ of sheep and $33.33 \%$ of goats.

In cattle, the adequate amount of liver copper is 25 to $100 \mathrm{ppm}$ wet weight (Puls, 1994), and the amount suggestive of copper deficiency is below 10 ppm wet weight (Brockman, 1977 and Frslie et al., 1980).

Taucher et al. (1975) recorded copper concentration $22.2 \mathrm{ppm}$ wet weight in Polish cattle, $8.8 \mathrm{ppm}$ wet weight in Irish cattle and 22.2 ppm wet weight in Australian cattle. Youssef et al. (1988) reported mean copper concentration of $9.94 \pm 0.28 \mathrm{ppm}$ dry weight in the livers of 
Egyptian buffaloes, also Mousa and Samaha (1993) reported copper concentration of $13.97 \pm 1.26,26.4 \pm 3.36$ and $71.28 \pm 7.96 \mathrm{ppm}$ wet weight in the livers of Egyptian buffaloes, cattle and sheep respectively.

Korsrud et al. (1985) recorded copper levels below $10 \mathrm{ppm}$ in $29 \%$ of cattle livers in Canada and Frslie et al. (1980) reported a 9.6\% incidence of low copper levels in cattle in Norway. The difference may reflect variation in soil and forage copper levels (Korsrud et al., 1985). Copper concentrations in organs which do not store the element may be more helpful decreasing only when the phase of dysfunction is approached. With the kidney for example, it is accepted that an increase in copper concentrations in the cortex above $0.4 \mathrm{~m}$ mol $/ \mathrm{kg} \mathrm{DM}$ indicates the likelihood of toxicity because values are normally kept within narrow range of 0.2 to $0.3 \mathrm{~m} \mathrm{~mol} / \mathrm{kg} \mathrm{DM}$ (Suttle, 1986).

In the present study, kidney copper concentrations were $10.87 \pm 3.48,6.01 \pm 0.51,5.61 \pm 0.43,8.08 \pm 1.64$ and $3.62 \pm 0.59$ for camels, buffaloes, cows, sheep and goats respectively. Similar results were previously reported in cattle by Korsrud et al. (1985) (5.4 ppm wet tissue) and Mousa and Samaha (1993) (6.51 $1.2 \mathrm{ppm}$ wet tissue). On the other hand higher concentrations of copper in kidneys were recorded by Henning et al. (1973) in cattle (17.1 ppm) and Mousa and Samaha (1993) in sheep $(22.75 \pm 3.47 \mathrm{ppm})$.

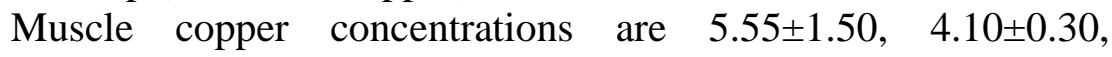
$4.52 \pm 0.37,7.23 \pm 1.35$ and $4.75 \pm 1.44 \mathrm{ppm}$ fresh weight in camels, buffaloes, cows, sheep and goats respectively. These values are in accordance with those recorded by Tanner et al. (1988) and Nasser (1995) in cows.

Blood is a more convenient tissue to collect from animals than most other tissues e.g. liver. Blood is easy to collect and blood analysis is the cheapest in total cost. Blood concentration only fall after there has been significant depletion of liver reserves (Gay et al., 1988). However, as liver biopsy seldom is a practical option in commercial herds, blood tests usually are used for routine assessment of mineral status in live cattle (Philip and Rogers, 2001)

The normal serum copper concentration ranges from 0.6 to $1.5 \mathrm{ppm}$ and serum copper concentration below $0.6 \mathrm{ppm}$ may indicate copper deficiency in cattle and concentration below $0.5 \mathrm{ppm}$ in lambs show copper deficiency symptoms (Beck, 1956).

The mean values of serum copper (Table, 1) are $0.9 \pm 0.15$, $0.79 \pm 0.05,0.78 \pm 0.08,0.75 \pm 0.14$ and $0.64 \pm 0.10$ (ppm) for camels, buffalos, cows, sheep and goats, respectively. These values lie within the 
safe adequate levels. In cattle, normal serum copper concentration ranges from 0.7 to $0.1 \mathrm{mg} / \mathrm{L}$ (Beck, 1956). Serum copper concentration $<0.6 \mathrm{mg} / \mathrm{L}$ may indicate copper deficiency in cattle (Tanner et al., 1988).

Copper concentrations in hair and wool are $7.44 \pm 2.01,7.84 \pm$ $0.48,6.92 \pm 0.90,10.03 \pm 1.90$ and $6.33 \pm 1.61 \mathrm{ppm}$ for camels, buffaloes, cows, sheep and goats, respectively.

Hair analysis is of limited value for evaluation of copper status because of the potential for contamination (Gay et al., 1988) and copper levels in hair samples are variable (Lazzaro, 2007).

A value of less than $5 \mathrm{mg}$ copper / $\mathrm{kg} \mathrm{DM}$ in a clean recently grown hair samples may indicate an increased risk of hypocuprosis in wool.

The results agreed with those recorded by Erdogan et al. (2003) and Kolacz et al. (1999) and in hair of healthy control goats by Unny et al. (2002).

Although there is variation in the copper level in different animal tissues examined in this study, there is no change in the organoleptic properties observed during examination of these samples.

\section{ACKNOWLEDGEMENT}

This study in sponsored through the Egyptian Finnish Agriculture Research Project (EFARP). The authors are greatly indebted to Prof. Dr. Hosni El-Sawah, Prof. Dr. Salwa Dogheim, Prof. Dr. Hoda Abdel Ghani and Prof. Dr. Ahmed Samy for their help and encouragement to fulfill this work.

\section{REFRENCES}

Beck, A.B. (1956): The copper content of the liver and blood of some vertebrates. Aust. J. Zool. 4: 1-18.

Brockman, R.P. (1977): Concentration of copper in livers of Saskatchewan cattle at slaughter. Can. Vet. J., 18: 168-170.

Bull, R.C. (1980): Copper. animal nutrition \& health / NovemberDecember 1980. Pp. 32-34.

Church, D.C. and Pond, W.G. (1988): Basic animal nutrition and feeding. $3^{\text {rd }}$ ed. Pp. 196-199. John Wiely and Sons, New York.

Claypool, D.W.; Adams, F.W. and Pendell, H.W. (1975): Relationship between the level of copper in the blood plasma and liver cattle. J. Anim. Sci., 41:911-914. 
Davis, G.K. and Mertz, W. (1987): Copper. In: W. Mertz (ed) Trace Elements In Human and Animal Nutrition. Pp. 301-364. Academic Press. San Diego, Ca.

Erdogan, S.; Erdogan, Z. and Sahin, N. (2003): An investigation of copper, zinc and cerulopasmin levels in serum, copper and zinc levels in wool samples of seasonal grazing sheep. Ankara Univ. Vet. Fac. Dergisi, 50 (1): 7-11.

Frslie, A.; Norhem, G. and Waassjo, E. (1980): Copper, Zinc and molybdenum in livers of Norwegian cattle at slaughter. Acta Vet. Scand., 21: 62-70.

Gay, C.C.; Pritchett, L.C. and Madson, W. (1988): Copper deficiency in ruminants. The Bovine Proceedings, No. 20: 134-138.

Hemken, R.W.; Clark, T.W. and Du, Z. (1993): Copper: its role in animal nutrition. In: T. Lyons (Ed) Biotechnology. I The Feed Industry. Pp. 35-39. Altech Technical Publications, Nicholasville, Ky.

Henning, A.M.; Groppel, A.B. and Ludke, H. (1973): Secondary copper deficiency in ruminants. In: W.G. Hockstra, (Ed.) Trace Element Metabolism In Animals. Pp. 726. Madison, W1.

Kolacz, R.; Bodak, E; Dobrzanski, Z. and Sokola, P.B. (1999): Trace elements in the wool of Polish Merino sheep in polluted and unpolluted environment. Czech J. Anim. Sci., 44(11): 409-511.

Korsrud, G.O.; Meldrum, J.B.; Salisbury, C.D.; Howahan, P.W.; Sachenbrecker and Tittiger, F. (1985): Trace element level in liver and kidney from cattle, swine and poultry slaughtered in cattle. Can. J. Comp. Med., 49: 159-163.

Larry, L. (1994): Effective copper nutrition for farm animals. Article by Ph. D. Professor, Animal Sciences University of Illinois.

Lazzaro, J. (2007): Basic information on copper deficiency in dairy goats in Southern California. Saanendoah dairy goats, Wincheste Temecula, California. The National Geochemical Survey, File Report 2004-1001. Updated January 2004.

Meret, S. and Henkin, R.T. (1971): Simultaneous direct estimation by atomic absorption spectrophotometry of copper and Zinc in serum, urine and cerebrospinal fluid. Clinical Chemistry, 17 (5): 369-373.

Mousa, M.M. and Samaha, I.A. (1993): Cadmium, copper, lead and Zinc in carcasses of food animals. Alex. J. Vet. Sci., 9 (3): 127-131. 
Nasser, M.H. (1995): Diagnosis of copper deficiency in cattle. $3^{\text {rd }}$ Sci. Cong., Egypt. Society for Cattle Diseases, Assiut Egypt., 78-81.

Philip, A.M. and Rogers, M.V.B. (2001): Copper, Iodine and selenium status in Irish cattle. End of project report, Project No. 4382, Teagase, Grange Research center, Dunsany, Co. Meath.

Phillippo, M. and Graca, D.S. (1983): Biliary copper secretion in cattle. Proceedings of the Nutrition Society, 42, 46A.

Puls, R. (1994): Mineral levels in animal health: Diagnostic data. $2^{\text {nd }}$ ed. Bc, Canada: Sherpa International. Pp. 356.

Suttle, N.F. (1986): Problems in the diagnosis and anticipation of trace element deficiencies in grazing livestock. Vet. Rec., 119: $148-152$.

Tanner, D.Q.; Stednick, J.D. and Leininger, W.C. (1988): Minimal herd sample size for determination of blood copper status of cattle. J. Am. Vet. Med. Assoc. 192: 1074-1076.

Taucher, S.R.; Nurmi, E. and Kerpanen, E. (1975): Control of copper, zinc, lead, cadmium and mercury in muscle, liver and kidney of Finnish cattle. J. Sci. Agr. Soc., Finland, 47:469.

Underwood, E.J. (1977): Trace elements in human and animal nutrition., $4^{\text {th }}$ ed. Academic Press, New York.

Unny, N.M.; Pandey, N.N. and Dwivedi, S.K. (2002): Biochemical studies on experimental secondary copper deficiency in goats. Indian J. Anim. Sci., 72 (1): 52-54.

Valentine, J.L.; Reisbord, L.S.; Kang, H.K. and Schluchter, M.D. (1987): Effects on human health of exposure to Se in drinking water. Pp. 675-687.

Youssef, H.; Hassan, H.A. and Gobal, A.F. (1988): Cadmium, copper and zinc in tissue of animals slaughtered in upper Egypt. 29 ARR Eitst Agung des Arbeitsgebietes Lebensmittethygiene.

Zervas, G.; Nikolan, E. and Mantzios, A. (1990): Comparative study of chronic copper poisoning in lambs and young goats. Anim. Production, 50: 497-506. 